\title{
Connecting Theory and Practice: A Review of the Work of Five Early Contributors to the Ethics of Management
}

\author{
Michael W. Small*
}

Curtin Business School, Western Australia 6102

\begin{abstract}
The purpose of this paper is to review the work of five people whose comments on ethical behaviour influenced the practice of management ethics as we know it today. The focus of the paper is on the theory expressed in the writings with which these five are associated viz.

(i) Anicius Manlius Severinus Boethius (C. 480-524/5?), the first of the scholastic schoolmen, was the author of De Consolatione Philosophiae (Consolation of Philosophy). The work consists of five books combining poetry and prose. Consolatione takes the form of a dialogue between Boethius and a personified 'Lady Philosophy'. Boethius addresses issues such as the desire or lust for power, the question of free-will, and the fact that life itself is temporary. They discuss the meaning of moral wisdom, happiness and virtue. They agree that happiness is the absolute good, and that wealth and earthly power do not mean very much. The only real and permanent quality is virtue.
\end{abstract}

(ii) Pope Saint Gregory I or Gregory the Great (540-60) was the author of Liber Regulae Pastoralis (Book of Pastoral Rule) (C. 590), the Commentary on Job - thirty-five volumes, sixty-five sermons, and a life of Saint Benedict. Liber Regulae Pastoralis addresses the selection of men for the Church, the type of life which they should lead, the best methods of dealing with the different types of people with whom they would have to deal, and the need for the pastor to guard himself against egotism and personal ambition. Liber Regulae Pastoralis was written primarily for senior clerics in the sixth century, but with a little imagination it could be used in teaching ethical management practice to modern day business executives.

(iii) Alfred the Great (849-901) was the last of the Anglo-Saxon monarchs. As the scholar/king he learnt to read and write Latin at the age of thirty-eight translating Boethius' De Consolatione Philosophiae, Bede's Historia Ecclesiasticus Gentis Anglorum (Ecclesiastical History of the English People), the Soliloquies of Saint Augustine and Pope Gregory's Liber Regulae Pastoralis into Anglo-Saxon or Old English. The reasoning behind this literary output was Alfred's desire to place his rule and that of his senior administrators on a firm intellectual basis. He used Liber Regulae Pastoralis as a reference for the moral and spiritual qualities required of those who had the responsibility of governing others.

(iv) Cardinal Stephen Langton (1155-1228) and Magna Carta (15 June, 1215) were chosen because issues such as rights, rectam justiciam (right justice), coram rege (power and the king's court), accountability, and ethical standards and behaviour were becoming evident during this period. Langton had sided with the barons who were opposed to the King over the details in Magna Carta (i.e. the Great Charter guaranteeing personal and political liberty).

(v) Sir Thomas More (1478-1535) was a barrister, and has been described as the most outstanding lawyer in our time in the way he dealt with the moral issues which were to cost him his life. He had lived in a Carthusian monastery and had considered becoming a monk. He had refused to accept Henry VIII as the Supreme Head of the Church. For More this was essentially a matter of conscience. A Dialogue of Comfort Against Tribulation was written in the Tower of London while sentenced to death, possibly by a reluctant Henry VIII-a similar situation to that of Boethius. In A Dialogue of Comfort Against Tribulation More addressed the causes of 'tribulation or grief' saying that the 'natural wise men of this world, the old moral philosophers, had laboured much in this matter, in respect to problems caused by matters of worldly wealth'. He demonstrated his professional ethics and his personal integrity by writing 'devout and virtuous instructions', prayers for his friends and even prayers for his enemies. According to Rawlinson, More was the first man in modern times 'to show us the way', referring to men in public life who might have to pay a high price if they were to maintain their moral position.

\section{INTRODUCTION}

Events in business and politics in this country, and possibly the rest of the western world seem to suggest that fraud, corruption and injustice on a grand scale are something new. In reviewing the writings of some of the early writers, it seems that this is not the case. People in positions of power and responsibility in these early days, they were usually

*Address correspondence to this author at the Curtin Business School, Western Australia 6102; E-mail: M.Small@curtin.edu.au churchmen or titled persons of some kind, were well aware of the legal, moral and ethical issues with which they had to deal. The purpose of this review therefore, is to look at the work of five people whose commentaries and observations in respect to ethical and moral behaviour greatly influenced the practice of ethical management as we know it today. The focus of the paper is on the theory expressed in their writings, and the practical consequences which evolved from this theory. A secondary purpose will be to compare the observations of these early commentators, and determine the extent 
to which they could be applied to contemporary problems in business and government.

\section{ANICIUS MANLIUS SEVERINUS BOETHIUS (C. 480-524/5?)}

Boethius was the first of the scholastic schoolmen, and the author of De Consolatione Philosophiae (Consolation of Philosophy). This work consists of five books combining poetry and prose. It takes the form of a dialogue between Boethius and a personified 'Lady Philosophy'. Boethius writes about the lust for power, the nature of free-will, and the fact that life itself is temporary. Boethius and a personified 'Lady Philosophy' discuss the meaning of moral wisdom, happiness and virtue. They agree that happiness is the absolute good, and that wealth and earthly power do not mean very much. The only real and permanent quality is virtue.

Boethius came from a distinguished Roman family, his father had been consul in 487. He was a public administrator (magister officiorum i.e. head of the civil service), the last of the Latin scholar/philosophers who had a good understanding of Greek, and the first of the new group of Christian scholastic philosophers. Boethius wrote De Consolatione Philosophiae (Consolation of Philosophy) in prison prior to his execution. (Sir Thomas More was also in prison awaiting execution when he wrote A Dialogue of Comfort Against Tribulation). According to Boethius/Watts (1969, p. 19) Boethius was 'unaided except by the power of his own memory and genius', suggesting that he had none of his books and references with him.

Consolation consists of five books of prose combined with thirty nine short poems. In Book I Boethius complains of his many injuries and his loss of reputation. In Book II Boethius argues a case that his fortunes should be restored to him. Book III Boethius writes that all men seek happiness, but make many mistakes along the way. Book IV, here Boethius asks why evil things happen to good people, and good things happen to evil people. Boethius argues that the good are powerful, and the others are impotent. All fortune is good, whether prosperous or adverse. In Book V, Boethius defends chance, free will and the prescience of God. Consolation takes the form of a dialogue mainly in parables between Boethius and 'Lady Philosophy'. 'Wisdom' and 'reason' are the two key themes through the five books. According to Boethius/Watts (ibid., p. 21) moral wisdom or philosophy was the philosophical basis or theme of Consolation. Boethius writes about the superficiality of materialism and wealth, and argues that things of the mind are superior to earthly things.

His theoretical philosophy was based on natural philosophy, the study of mathematics and theology. Boethius' practical philosophy was based on 'the pursuit of wisdom and the love of God'. This was the only way, he argued, of finding happiness. Beatitudo i.e. happiness or beatitude or blessedness or virtue came from within a person, and could never be taken away. Boethius stated 'for in every ill-turn of fortune the most unhappy sort of misfortune is to have been happy' (Book II, prose iv). He referred to happiness again cited in McKeon (1958, p. 433):

as the state perfect by the aggregation of all goods; its principle is stability of confirmation in the good; it consists in the most perfect operation of one possessed of reason and intellect;

Happiness was the absolute good, and it was obvious that all good men became good by virtue of the very fact that they were good (Book IV, verse 11, p. 305). Boethius' practical philosophy included ethics and morals, politics based on the cardinal virtues (justice, prudence, temperance and fortitude); and economics (i.e. the management of a household or family). Life was transitory, uncertain and was never wholly obtained nor lasted e.g. 'a rich man might have gold mines, pearls and oxen in his fields', he would still have 'biting cares', and when he died his wealth would remain behind. Boethius argued that the rich and greedy could access wealth that would never satisfy them. A person might 'deck himself with pearls from the Red Sea's shore, and plough his fertile field with oxen by the score', yet there would always be a gnawing care that would never in his lifetime leave him, and when he died his wealth would remain behind (Book III, verse III, p. 239). A man might be wealthy, and condemned for his 'base lineage'. Another person might have come from a noble family, but if he was penniless, he would prefer to be unknown (Book II, verse IV, p. 19).

The English translations seem to vary greatly with a lot of poetic licence. As an example, one translation reads: 'Who mildly can his age dispose, And at his feet proud destiny throws: Who stoutly does his chance behold, Keeping his countenance controlled:' Another translation reads: 'He who has calmly reconciled his life to fate, and set proud death beneath his feet, can look fortune in the face, unbending both to good and bad: his countenance he can shew' (Book I, verse IV, p. 141).

With respect to power, we read that if someone wanted power, that person would have to curb his affections and his lust. Foreign lands might tremble when they knew he was around, but at the end of the day his real power and might was 'small or none' (Book III, verse V, p. 247). With respect to the topics of 'will' and 'power', Boethius reasoned that these were the two qualities which affected all human actions, for if one was lacking, nothing could be performed. For if there was no will to undertake a task, a man could not achieve anything against his will, and if there was no power, the will would be in vain (Book IV, verse 11, p. 305).

According to Lady Philosopher, there could be no reasonable nature, unless it endued with free will. Lady Philosopher argued that there was free will, and that there could be no reasoning nature without freedom of judgement. For any being that could reason, had a power of judgement by which it could without further aid decide each point, and so distinguish between objects to be desired and objects to be shunned (Book 5, verse II, p. 371).

These examples illustrate Boethius' style and approach. They were written in the $5^{\text {th }}$ century $\mathrm{AD}$, and demonstrate that human nature is much the same today as it was in Boethius' time. The advice that Boethius gave in $524 \mathrm{AD}$ is still relevant. Boethius' comments could be applied to a minority, whose management practices we hear and read about in the media. Boethius believed that 'happiness' could only be achieved by following a way of life based on the pursuit of moral wisdom and the cardinal virtues (justice, prudence, temperance and fortitude). 
Currently all states have some form of a Corruption and Crime Commission. The revelations from the hearings of these Commissions suggest that there are some people in government, business and politics today who demonstrate similar characteristics to which Boethius was referring in $5^{\text {th }}$ century AD. As a post script a more recent publication, with similar title The Consolations of Philosophy (De Botton, 2000) adopts an updated approach to the study of this area.

\section{POPE SAINT GREGORY I OR GREGORY THE GREAT (540-60)}

Gregory was the author of Liber Regulae Pastoralis (Book of Pastoral Rule) (C. 590), Magna Moralia (A Commentary on Job, consisting of thirty-five volumes), sixty-five sermons, and a life of Saint Benedict. Liber Regulae Pastoralis was written mainly for senior clerics in the sixth century, but it could be a used, with some modifications, in teaching ethical management practice to modern day business executives.

In addition to a prodigious research output, Gregory was an active church administrator. He sent Augustine to found the English church at Canterbury in 596, and is supposed to have said non Angli, sed Angeli (cited in Bede, 1994) when he saw the blue eyed, blonde haired and fair skinned (Angle) boys who were for sale in the Roman slave market.

Liber Regulae Pastoralis was Gregory's major work. It is divided into four parts, and covers the selection of men for the church; the type of life they should lead; the best methods of dealing with the different types of people with whom they would have to deal; and the need for the pastor to guard himself against egotism and personal ambition. Written for senior churchmen in the sixth century, Liber Regulae Pastoralis could be read today and still be meaningful. Churches and religious denominations have different agendas to business organisations, but there are similarities in the way church executives and business executives carry out their respective roles.

The section below paraphrases the advice that Gregory gave to his senior church officials in the sixth century AD, and as in the previous section on Boethius, the advice that Gregory gave to his subordinates has meaning for today's management executives. Allowing for some literary licence, the words senior executive could replace bishop or pastor, and organisation could replace church.

Part i. 'Who Should Rule in the Church? Or the Selection of Men for the Church'. Gregory argued that some men were totally unfit to have become bishops. No one did more harm in the church than the one who had the name and rank, but acted perversely. Even when a man had learned humility in the school of adversity, and he came to a position of power and authority, he changed and became elated by his familiarity with glory. Often the care of government when undertaken was a distraction and a person could be found unequal to dealing with particular things. Some men were very capable of ruling in a church, but sometimes they chose to abdicate their responsibilities, and not always for the highest of motives. If a man claimed humility as a reason for not taking on the office of bishop, then true humility would mean that the man should not reject what the church had asked him to do. The man who accepted the office of bishop should know something about the role of that position. Some men sought higher office for unworthy motives. It was therefore difficult to learn humility in high places. A person's past life should be examined to see if he had learnt humility, and not be flattered by praise. The man, who was destined to rule, should already be living an exemplary religious life.

Part ii. 'The Moral Qualities of a Bishop'. A bishop should be discreet and keep silent. He should be profitable in speech, but he should always be ready to act. At the same time, he needed to exercise humility, discipline and compassion.

Part iii. Gregory wrote that he was obliged to advise, warn and as he says 'admonish a wide variety of people'. He listed the different groups of people with whom a bishop would have to deal i.e. men/women, rich/poor, sad/joyful, wise/dull, superordinates/subordinates, the humble/the haughty etc. The following illustrates differences in attitudes at that time.

In serious matters you have to talk to men in a different way than you talk to women. You cannot admonish the old in the way you might admonish a young person. Some people are bright and knowledgeable, some are impudent, some are enthusiastic, and some are crafty and insincere. Admonishment had to be administered differently.

Part $i v$. This section addressed the need for bishops to guard against egotism and personal ambition and advocated a time for self-examination. Gregory warned bishops, who might have taken delight in self-display, that great care would be needed, lest they did themselves harm. Gregory was concerned about bishops who did not demonstrate sufficient 'humility' (the word appears six times) as opposed to 'hubris'.

\section{ALFRED THE GREAT (849-901)}

Alfred was the last of the Anglo-Saxon monarchs. As the scholar/king he learnt to read and write Latin at the age of thirty-eight translating Boethius' De Consolatione Philosophiae, Bede's Historia Ecclesiasticus Gentis Anglorum (Ecclesiastical History of the English People), the Soliloquies of Saint Augustine and Pope Gregory's Liber Regulae Pastoralis into Anglo-Saxon or Old English. The reasoning behind this impressive literary output was Alfred's desire to place his rule and that of his senior administrators on a firm intellectual basis. He used Liber Regulae Pastoralis as a reference for the moral and spiritual qualities required of those who had the responsibility of governing others.

According to Coote (1993, p. 9) Alfred's translation of the Latin Liber Regulae Pastoralis into Anglo-Saxon:

demonstrated his desire to place his rule and that of his senior administrators on a firm intellectual basis, for Liber Regulae Pastoralis describes the moral and spiritual qualities required of those who have the government of others.

These activities demonstrated a very high degree of literary and linguistic skill which Alfred undertook for the benefit of his subjects. As military strategist, Alfred demonstrated a high degree of military skill. For example, he reorganised the fyrd (the army prior to the Norman Conquest) into two halves. Each half serving for periods of about six months, thus allowing the other half to return home and gather the 
harvest. He constructed burhs the fortifications or strong points (boroughs or burghs in modern English) and a fleet of ships.

\section{CARDINAL STEPHEN LANGTON (1155-1228) AND MAGNA CARTA (15 JUNE, 1215)}

These were chosen because issues such as rectam justiciam (right justice), coram rege (power within King John's court), accountability, rights, and ethical standards and behaviour were becoming evident during this period. Langton had sided with the barons who were opposed to King John over the details in Magna Carta, the Great Charter guaranteeing personal and political liberty. Carta contains principles of law that are still in use today e.g. habeas corpus ad subiiciendum, (thou shalt have the body in court). This was a writ requiring a person be brought before a judge or into court so that a charge could be properly and legally investigated.

According to Hudson (1996, p. 220-224), coram rege i.e. the court of King John (1199-1216) had become significant in the administration of 'royal dominated justice' and 'royal power'. This seemed to be a haphazard affair depending on the King's wishes at the time. There were numerous disputes over issues involving 'justice'. Ethical behaviour was promoted amongst the legal profession, partly because the King wanted to promote accountability among his servants, but as Musson (2001, pp. 50-51) argued there was also a desire for impartiality in judicial and legal inquiries. Ethical standards and ethical behaviour were beginning to become more evident. Royal justices took an oath on appointment and were expected to be diligent in the exercise of their duties. They were expected to uphold rectam justiciam (right justice). Royal justices and barons of the exchequer had to swear (C. 1257) that 'they would not accept, either directly or indirectly, any gift or service from anyone whom they knew was a litigant in a case they were expected to deal with'. The oath was revised with an explicit concentration on standards of judicial conduct:

To do justice to the best of his ability to all as well poor as rich...not to disturb or respite justice against right or against the law of the land either for the great or the rich, nor for hatred nor for favour nor for the estate of anyone nor for a benefit,.........

Robertson (1999, p. 3) has cited Article 40 'to no man will we sell, to no man will we delay or deny justice or right'. He argued that this appears to be the forerunner of the European Convention on Human Rights. The section includes the comment that everyone is entitled to a fair hearing within a reasonable time. A parallel could be drawn here in respect to the prisoners held today in Guantánamo Bay.

At this time the Pope, Innocent III (1198-1216) told King John that he would like Stephen Langton to be the next Archbishop of Canterbury. According to Powicke (1965, p. 31), the Pope stated that Langton was a 'gentleman, a scholar, and a canon of York, a more important church than the church of Paris'. However, Stephen, Archbishop of Canterbury, Primate of all England and Cardinal of the Holy Roman Church had sided with the barons who were opposed to the King. The point of the dispute was in the detail in Magna Carta. Langton had also opposed the Pope's envoy, Pandulf. During the dispute between the King and the bar- ons, Langton had arranged a truce while negotiations took place in respect to the wording of the sixty-three provisions of Magna Carta. The result of Cardinal Langton's opposition to both King and Papal Legate was that he lost his position as Archbishop of Canterbury in 1215. However he regained it later during the reign of Henry III (1216-1272).

Robertson (ibid., 2-3) has argued that the appearance of 'rights' as a set of popular propositions limiting the power of the Sovereign is usually traced to Magna Carta. However, in Robertson's (ibid.) view it was really a case of a feudal king feuding with thuggish barons. Valente (2003, p. 12) has described Magna Carta as the cornerstone of Anglo-American political liberty, and that 'it was the duty of the realm to use force against the king in the cause of justice'.

Carta contains principles of law that are still in use today. The idea of habeas corpus ad subiiciendum, Habeas Corpus (thou shalt have the body in court) was a writ requiring the body of a person to be brought before a judge or into court so that a charge could be properly and legally investigated. It was not until 1679 that the Habeas Corpus Act and the Exclusion Bill became law in the reign of Charles II (1660-1685). Other clauses in Carta include the protection of a widow's property rights, the confirmation of liberties, free customs of all cities and ports and the establishment of courts of law to hear cases.

Magna Carta is still a significant document. Ross Perot (onetime aspirant to the White House) owns one of four Inspeximus (ink-on-vellum documents written in 1297) versions valued (1984) at \$US 1.8 million. They followed three editions of the Carta initially agreed to in 1215. Another copy is held at Parliament House, Canberra. This was valued at \$A 40 million in 2002, but later was re-valued at \$A 15 million (January 2006).

\section{SIR THOMAS MORE (1478-1535)}

Sir Thomas More has been described as the most outstanding lawyer in our time in respect to the way he dealt with the moral issues which were to cost him his life (McCarthy and Reynolds, 1995). More's A Dialogue of Comfort Against Tribulation was written in the Tower of London while sentenced to death, possibly by a reluctant Henry VIII. Ackroyd (1998, p. 385) has described how Cromwell:

then tried to kill More with kindness, professing the benevolent intentions of a king who would be willing to show mercy and allow his old servant to be abroad in the world again among other men.

The reason for More's execution was his refusal to accept Henry as the Supreme Head of the Church (Rawlinson cited in McCarthy and Reynolds, 1995, p. 55). For More, it was essentially a matter of conscience. The Academy Award winning film, "A Man for All Seasons", could be a useful devise here to illustrate the power of conscience. More knew that it was not right for Henry to be Supreme Head of the Church, even though the Papacy was in a state of disarray at that time. Martin Luther's ideas about reforming the church were about to take over in Europe, and More might have been favourably disposed towards these new ideas had he survived. 
More's background is probably more familiar than that of Boethius. He was a successful barrister (1496-1510), lived in a Carthusian monastery and had considered becoming a monk. In 1504, then aged only 26 or 27 he demonstrated his opposition to King Henry. He spoke in Parliament against the King's demand for a subsidy for the Prince of Wales who was already deceased, and for a marriage allowance to Princess Margaret who had gone north to marry James IV of Scotland. 'The King's demands were clean overthrown' by More's intervention (ibid., p. 23).

During the period when he was in favour with Henry, More was the under-Sheriff of London (1510-18, salary $£ 400$ p.a.), Master of Requests and Privy Councillor (1518), knight and sub-treasurer to the king (1521), Speaker of the House of Commons (1523), Chancellor of the Duchy of Lancaster (1525) and Lord Chancellor (1529-1532).

His fortunes changed dramatically in 1529 when Henry decreed his own divorce through Archbishop Cranmer, claiming to be head of the Church in England thus denying the jurisdiction of the Pope. This was schism, a total separation from the Catholic Church. More declined the invitation to attend the coronation of Anne Boleyn in June 1533, refused to take the Oath of Royal Supremacy on at least three occasions and to swear to the Act of Succession in April 1534. These were courageous decisions, which led to Henry turning against him. From then on More knew his life was in danger. Warrington cited in More (1955, pp. x-xi) noted that:

More's character was as near to perfection as our nature would permit. He was the supreme instance of nature perfected by grace. His natural talents were ennobled by a life of unsullied virtue, and that life in turn was crowned by a most glorious martyrdom.

More addressed the causes of 'tribulation or grief' in $A$ Dialogue of Comfort Against Tribulation saying that the 'natural wise men of this world, the old moral philosophers, had laboured much in this matter, in respect to problems caused by matters of worldly wealth'. He demonstrated his professional ethics and his personal integrity by writing 'devout and virtuous instructions', prayers for his friends and even prayers for his enemies. Letters (dated 16 January 1535, 2 March 1535, 5 July 1535) compiled by Rogers (1967) written whilst he was in the Tower give a moving description of the last months of his life. Many are addressed to Margaret Roper, his daughter, (ibid., pp. 148, 236, 245) and to Master Leder, a priest (ibid.: 243). Most are written with a 'coal' (i.e. charcoal) and all of them demonstrate More's ability to express his thoughts under very difficult circumstances. His final letter to his daughter written on 5 July 1535, the day before his execution is one such example.

Rawlinson cited in McCarthy and Reynold (eds., 1995, p. 6) stated that:

More delimited for us, for all time, the final duty which, in one way or another, in one degree or another all of us at some time may be called to face.

According to Rawlinson, More was the first man in modern times 'to show us the way', referring to men in public life who might have to pay a high price if they were to maintain their moral position. Brennan (ibid., p. 7) referred to More's 'integrity of conscience, and his quintessential pro- fessional virtue'. Baker-Smith (2000, p. 10) referred to More's moral awareness which he had developed when very young. More (1808, p. 117) addressed his problem with concupiscence. He referred to his 'penances and mortifications' which he had practised from the ages of eighteen and twenty years. He sought to tame his urges by wearing 'a sharp shirt of hayre next his skin, much fasting, lying on the bare ground, and having only four to five hours sleep in a night'. More (ibid., p. 90) stated in Utopia:

In that philosophy, which intreateth of manners and vertue (notes here suggest that vertue be translated as moral philosophy) their reasons and opinions agree with ours. The chief and principal question is, in what thing, be it one or more the felicity of man consisteth?

\section{CONCLUSION}

The purpose of this paper was to review the work and influence of five early scholars, Boethius, Pope Gregory, Alfred the Great, Cardinal Langton and Sir Thomas More, who had addressed a range of topics in the field of applied ethics and moral wisdom. These five had addressed or referred to the intellectual, moral and spiritual qualities that were required of people who were charged with the control of others. They came to the conclusion then, that greed (which seems to be the primary cause), worldly wealth (which eventually has to be left behind), and the lusting after power were and are still major sources of discontent. Power and position could and did change people-usually for the worse. On a positive note, the five had similar advice for their followers and/or subjects viz.: (i) follow the cardinal virtues (i.e. justice, prudence, temperance and fortitude); (ii) accept that materialism and worldly wealth are superficial; (iii) practise humility, discipline and compassion; (iv) be impartial and fair in matters legal and judicial; (v) acknowledge that people have rights; (vi) follow the dictates of conscience if moral guidance was needed; and (vii) only by pursuing a moral and virtuous life could the 'happiness' to which most people aspire be found.

Now if this advice seems unrealistic for a modern business executive or politician to follow, a few examples might convince the sceptical reader. In one Australian state, the Corruption and Crime Commission revealed (April 2007) a range of activities which required the Premier to ask a number of ministers for their resignation. He also issued instructions that members of the government were not to meet with certain well-known lobbyists. In one case, it was assumed that a member of the Legislative Council, the State upper house, would offer her resignation for breaching the Premier's code of conduct which had been revealed by the Crime and Corruption Commission. However, in an ABC TV interview (23/03/2007) the member explained (unconvincingly) that she had no intention of resigning, but intended remaining a member of the state upper house, thus supporting Boethius' comments about people lusting after power. In the Commonwealth Parliament a similar situation is being played out. Again two ministers were asked to resign their portfolios. 'Forgetfulness' and 'just an honest mistake' were given as excuses for breaching the Prime Minister's code of behaviour. Again the Prime Minister has had to remind his parliamentary colleagues about their moral and 
legal obligations to record their business and share transactions in the pecuniary interests registry, and to state whether these business interests involved conflicts of interest.

In terms of justice, fair play and simple honesty, the following examples illustrate that some people have taken business crime to new heights. In 1985, Enron's two senior executives, Kenneth Lay and Jeffrey Skilling, were charged with fraud and conspiracy. Andrew Fastow, the company's $\mathrm{CFO}$, was gaoled. Arthur Anderson, the accounting firm that approved Enron's financial status was later convicted of conspiracy. Dennis Kozlowski, CEO Tyco tried to get $\$ 17.8$ million in legal costs from his insurance company. He was charged with grand larceny and enterprise corruption, but he is probably best known for his $\$ 6,000$ shower curtain and the ice statue of David. Worldcom's CEO Bernard Ebbers was sentenced to twenty-five years in gaol. The examples are endless, and there seems to be no end to them.

\section{REFERENCES}

Ackroyd, P. (1998). The Life of Thomas More, New York: Doubleday.

Baker-Smith, D. (2000). More's Utopia, Toronto: University of Toronto Press in association with the Renaissance Society of America.

Bede, (1994). Historical Works, Volumes I and II, Translated by J.E. King, The Loeb Classical Library, Cambridge, Mass.: Harvard University Press, Historica Ecclesiatica, II.i.

Boethius, (1953). Consolation of Philosophy, English Translation Revised by H.F. Stewart, The Loeb Classical Library, London: William Heinemann Ltd., Cambridge, Mass, Harvard University Press.

Boethius. (1969). The Consolation of Philosophy, Translated with Introduction by V.E. Watts, London: Penguin Books.

Bury, J.B. (1958). History of the Later Roman Empire, Volume I, New York: Dover Publications.

Coote, S. (1993). The Penguin Short History of English Literature, London: Penguin Books.

De Botton, A. (2001). The Consolations of Philosophy, Australia: Penguin Books.
Hudson, J. (1996). The Formation of English Common Law, Law and Society in England From the Norman Conquest to Magna Carta, London: Longman.

McCarthy, J. and Reynolds, A. (Eds.). (1995). Thomas More The Saint and The Society Sydney: St Thomas More Society.

McKeon, R. (Ed.). (1958). Selections from Medieval Philosophers, Volume II, and New York: Charles Scribner's Sons.

More, Thomas Sir Saint. (1808). Most pleasant, fruitful, and witty work of the best state of a public weal and of the new isle called Utopia, notes and literary introduction by T.F. Dibdin, (London: Printed byWilliam Bulmer at the Shakespeare Press, for William Miller Bookseller and Publisher, in Albermarle Street.

More, T. (1955). More's Utopia and A Dialogue of Comfort Introduction by John Warrington, No. 461 in Everyman's Library, (London: J.M. Dent and Sons).

Musson, A. (2001). Medieval law in context: the growth of legal consciousness from Magna Carta to the Peasants' Revolt, Manchester: Manchester University Press.

Powicke, M. (1965). Stephen Langton Being The Ford Lectures Delivered in the University of Oxford in the Hilary Term 1927, London: Merlin Press.

Robertson, G. (1999). Crimes Against Humanity The Struggle for Global Justice Allen Lane: The Penguin Press.

Rogers, E.F. (Ed.). (1967). St. Thomas More: Selected Letters, New Haven and London: Yale University Press.

Thomas, J.A.C. (1975). The Institutes of Justinian Text, Translation and Commentary, Amsterdam, Oxford: North-Holland Publishing Company.

Valente, C. (2003). The Theory and Practice of Revolt in Medieval England, (Aldershot and Ashgate).

\section{FOR FURTHER READING}

Bragues, G. (2005). Business is One Thing, Ethics is Another: Revisiting Bernard Mandeville's The Fable of the Bees, Business Ethics Quarterly, 15 (2).

Stackhouse, M. L., McCann, D. P., Roels, S. J. and Williams, P. N. (eds.). (1995). On Moral Business: Classical and Contemporary Resources for Ethics in Economic Life, Grand Rapids: William B. Eerdmans.

Wren, D. A. (2000). Medieval or Modern? A Scholastic's View of Business Ethics, circa 1430, Journal of Business Ethics, 28 (2), November, II. 